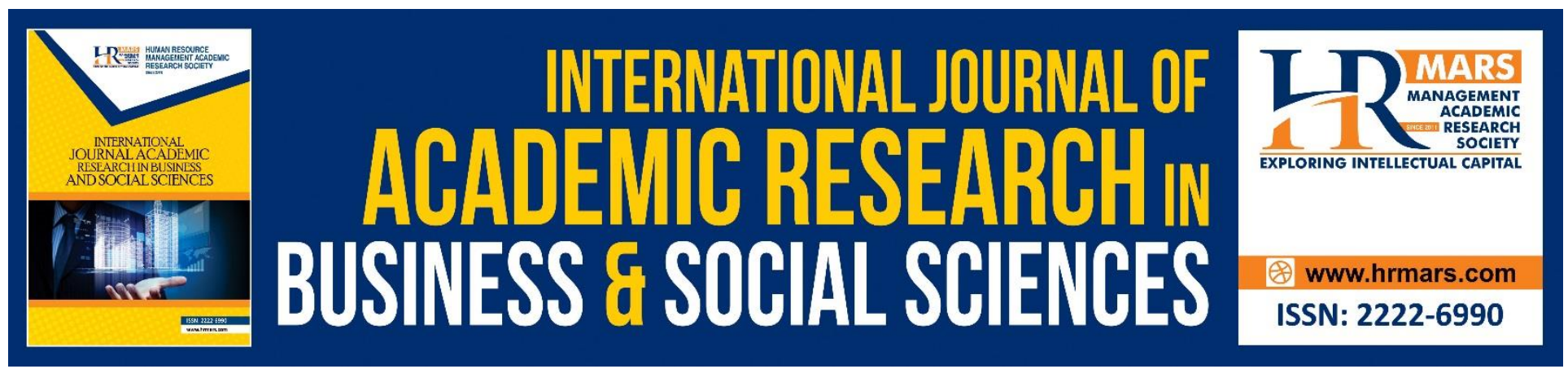

\title{
Haji Abdullah Idris: Kelantan Intellectual Sufi of the 20th Century
}

Mohamed M.L., Omar S.H.S., Abdullah W.I.W., Ismail M.S., Wan Jusoh W.H. \& Wok Zin E.I.E.

To Link this Article: http://dx.doi.org/10.6007/IJARBSS/v8-i10/4716 DOI: $10.6007 /$ IJARBSS/v8-i10/4716

Received: 17 Sept 2018, Revised: 11 Oct 2018, Accepted: 21 Oct 2018

Published Online: 30 October 2018

In-Text Citation: (Mohamed et al., 2018)

To Cite this Article: Mohamed, M. L., Omar, S. H. S., Abdullah, W. I. W., Ismail, M. S., Wan Jusoh, W. H., \& Wok Zin, E. I. E. (2018). Haji Abdullah Idris: Kelantan Intellectual Sufi of the 20th Century. International Journal of Academic Research in Business and Social Sciences, 8(10), 100-108.

Copyright: (C) 2018 The Author(s)

Published by Human Resource Management Academic Research Society (www.hrmars.com)

This article is published under the Creative Commons Attribution (CC BY 4.0) license. Anyone may reproduce, distribute, translate and create derivative works of this article (for both commercial and non-commercial purposes), subject to full attribution to the original publication and authors. The full terms of this license may be seen

at: http://creativecommons.org/licences/by/4.0/legalcode

Vol. 8, No. 10, 2018, Pg. 100 - 108

http://hrmars.com/index.php/pages/detail/IJARBSS

JOURNAL HOMEPAGE

Full Terms \& Conditions of access and use can be found at http://hrmars.com/index.php/pages/detail/publication-ethics 


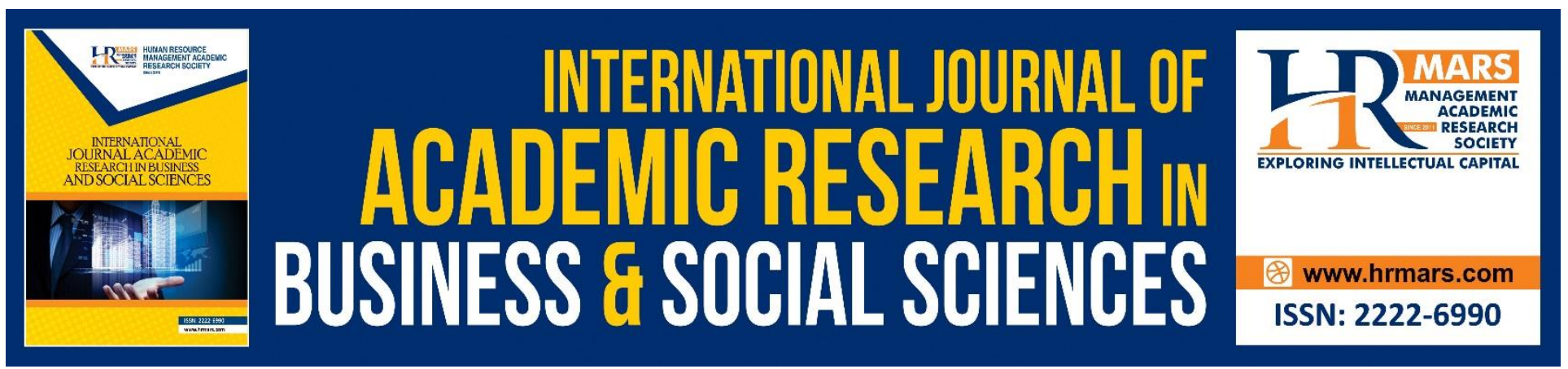

\title{
Haji Abdullah Idris: Kelantan Intellectual Sufi of the 20th Century
}

\author{
Mohamed M.L. ${ }^{1}$, Omar S.H.S. ${ }^{1} 4^{*}$, Abdullah W.I.W. ${ }^{3}$, Ismail M.S. ${ }^{4}$, \\ Wan Jusoh W.H. ${ }^{4}$ \& Wok Zin E.I.E. ${ }^{4}$ \\ ${ }^{1}$ Institute of Islamic Product Research and Islamic Civilization, Universiti Sultan Zainal Abidin, \\ Malaysia. \\ ${ }^{3}$ Center for Industrial and Community Networkings, Universiti Sultan Zainal Abidin, Malaysia. \\ ${ }^{4}$ Faculty of Islamic Contemporary Studies, Universiti Sultan Zainal Abidin (UniSZA), Malaysia. \\ *Corresponding Author: sylutfi@unisza.edu.my
}

\begin{abstract}
The arrival of Islam to the Malay World's region has contributed excessively to the development of conception, intellectual and writing among the Malay community. The state of Kelantan also received some gist of the flow of development, in the sense of the birth of many clerics and intellectual figures from the 19th century to this day. the aim of this article is to explain the role of an intellectual Sufis towards the intellectual development in the state of Kelantan. He is Haji Abdullah Haji Idris, the leader of the Ahmadiyya Sufis Order lineage with Haji Daud Bukit Abal who has not yet been featured in academic studies. This article briefly reviews the biography of the Sufi and reflects on his personality as a scholar who is concerned with his environment. The study found that he was a religious, entrepreneur and a scholar that has shares in the development of the Ahmadiyya Sufis Order and contributed to the rising of the realization among Kelantan's Malay community. The disclosure of this figure is hoped to act as a guide to researchers in the field of leadership.
\end{abstract}

Keywords: Haji Abdullah Idris, Intellectual Sufis, Tarekat Ahmadiyyah

\section{INTRODUCTION}

Sufism was founded in Kelantan before Tuan Tabal (1840-1894) began actively spreading the Ahmadiyyah order in Kota Bharu in the 1870s. From the historical study of the Kelantan clerics there are some prominent religious scholars who follow the orders other than the Ahmadiyyah namely Syaziliyyah and Syatariyyah. The Syaziliyah Tarekat held by Tok Pulai Chondong (1793-1873) was followed by Wan Ali Wan Abdul Rahman known as Wan Ali Kutan (1837-1913) and Wan Muhammad bin Tuan Tabal (1870-1920), the former mufti of Kelantan. While the Syatariyya Sufis Order was followed by Tok Chekeli, Haji Yaakub Haji Muhammad Said (1838-1907) and Haji Taib Tuan Padang (1857-1947) and Mufti Wan Muhammad Tuan Tabal (Daud, 2012; Harun, 2015). This article focuses 
on an intellectual Sufi figure in the land of Kelantan, hence this article will enlighten the biography of Haji Abdullah Idris encompassing birth and marriage. Next in the second chapter also explains the levels of his intellectual development, his experience with the Kelantan Minister, his business experience, then the teachers and students in the path of solitude and ended with an explanation of his concern to the Kelantan community. With this exposition it gives a clear picture of the personality biography and accomplishes the scientific study material on the character.

\section{METHODOLOGY}

This qualitative study uses data collection and data analysis methods. Data collection methods through libraries and special interviews with families and previous research figures were conducted to obtain information on biographies and concerns to the people of Kelantan.

\section{RESULTS AND DISCUSSIONS}

\section{Biography of personality}

His full name is Haji Abdullah bin Haji Idris bin Haji Noh was born in Kampung Gajah Mati, Kota Bahru Kelantan in 1909 M. He is the third of six siblings (Auni, 2017). His early education at Padang Garong Malay School, then to Religious School of Muhammadiah. Then proceed to Pondok Tok Khatib Haji Nik Abdullah Haji Abdul Samad, then Pondok Haji Ahmad Hakim Abdul Manan in Kubang Pasu and finally Pondok Haji Yaakub Haji Ahmad in Lorong Gajah Mati Kota Bahru Kelantan. His entourage in the world of Sufism began as soon as he entered the cottage education in 1924. At this point also the inclination of intellectuality has emerged arising from his intense reading interest covering various genres of writing other than the field of religion. At this point his interest in writing newspaper and magazine articles (Mahirah, 2018).

During his life, Haji Abdullah came across a wide array of movements that he had devised for his future. His life flow from the beginning did not lead him to become a scholar who directly involved in religious education. In the long run from 1928 to 1948, he was in two different worlds, being a clerk of assistant Dato' Perdana, the Chief Minister of Kelantan and then entering the business world. His involvement in these two areas does not affect his or her tendency to lead a spiritual life and does not condemn his intellectual interest. It is even proven that both experiences become an essential ingredient that builds on her identity as an intellectual Sufi.

\section{Intelligence}

As a result of the reading of the historical and the newspaper by his grandfather, Pak Mat Hassan from childhood was not in vain with his appearance as a teenage foot and subsequently forming his intellectual level. His intellectual stimulus grew steadily while studying in Madrasah Muhammadiyah under the guidance of four Malay intelligentsia at the time, Muhammad Adnan Muhammad Arifin, Megat Othman Megat Muhammad Ali, Che Mat Baba and Muhammad Ghazali Muhammad Arifin. Haji Abdullah has been keen on all developments in the field of education, intellectuality and local and international politics.

His intellectual level increased after he was elected as Assistant Minister of Kelantan Dato' Perdana Menteri, Nik Mahmud Ismail (1880-1964) in 1928. The experience of working with the Chief 
Minister of Kelantan has sharpen his intellectual talent as he has been exposed to the intricacies of government, understand the English colonial idolatry, hear the criticisms and analysis from Dato' Perdana's own mouthpiece on local and international politics, criticisms of Malay figures of magnificence, and figures of Malay scholars. His sweet experience with Dato 'Perdana was to produce a book titled "Citra Kelantan" in 1933, which was a measure of learning in Kelantan Schools (Auni, 2017). In 1933 he decided to quit because he did not want to be bound by Certain parties. Then he ventured into the field of timber company by having three factory buildings located at Kampung Atas Paloh, Kota Bharu. In 1948 his woodworker was involved with the fire, so he decided not to redevelop the timber plant because he wanted to concentrate on the life that was stuck until the end of his life (Anisah,2018).

\section{Spiritual Life}

His involvement in the world of Sufism path has undergone a major transformation after the Ahmadiyya Sufis order by Sidi Muhammad Azahari, a great Arabian saintly figure at the age of 16 and was given a personal robe by Sidi Muhammad Azahari and was given a call (anta rijal) which means the real man according to interpretation of his teacher, Tok Khatib Hajj Nik Abdullah (Anisah, 2018). His involvement as an Ahmadiyya commander began after his marriage in 1934, accompanied by a group of Ahmadiyya Sufis order in his mosque, Haji Abdus Salam in Kampung Kubang Pasu, Kota Bharu. Disciples of Sufis path mostly come from around Kota Bharu, Kampung Laut, Kuala Krai and Southern Thailand (Anisah, 2018). He and his brother-in-law (Yahya Abdul Salam) produced a small pamphlet, so called "Awrad al-Awliya" was published and distributed free by the Kelantan Islamic Religious Affairs Department with verification confirmation by Kelantan Deputy Mufti, Haji Ismail Yusuf in 1988 (Salam, 1988). So when he addressed the Divine call on October 4, 1994, he continued to serve those who visited him for spiritual guidance from him (Rahman, 2017).

Haji Abdullah Idris is a Sufi figure and the Ahmadiyya commander in Kelantan who rarely said. As far as possible, there are some names of teachers who have taught him in the sciences of Sufism among them, Tok Khatib Haji Nik Abdullah bin Haji Abdul Samad, Haji Ahmad Mannan, Haji Yaakub Haji Ahmad Gajah Mati, Haji Abdul Salam Muhammad and Haji Che Muhammad Amin Che Wan Bechah Keranji. While his disciples are able to be judged, Haji Shuib Haji Daud, Kampung Menuang, Kota Bharu, Haji Wan Abdul Razak (Wan Jak), Kampung Laut, Haji Othman, Kampung Laut, Haji Nik Mat Jakan, South Thailand, Nik Sulaiman, Kampung Laut , Haji Omar Janggut, Kula Krai and Ustaz Haji Yahya Abdul Salam.

\section{Manifestation of life an Intellectual Sufi}

His life journey reflects the manifestation of his spiritual life and his intellectual appearance that goes hand in hand. This is in line with self-sufficiency as a Sufi who is concerned with the environment and not forgetting social responsibility. In venturing into the spiritual realms, he proved negligent from carrying out community responsibilities. Haji Abdullah has been keen on all developments in the field of education, social, intellectual and local and international politics. This has positioned itself as a discerning observer of the change and turbulence that has taken place despite the profound tendency in the world of loyalty. As a Sufi who is decorated with intellectual appearance, he often 
INTERNATIONAL JOURNAL OF ACADEMIC RESEARCH IN BUSINESS AND SOCIAL SCIENCES Vol. 8, No. 10, Oct. 2018, E-ISSN: 2222-6990 @ 2018 HRMARS

appears to show concern for the environment. The manifestation of his identity is clearly evident in the following aspects:

i. Community

While entering the business world, Haji Abdullah Idris always paid attention to the question of public interest in business conduct. It covers in relation to its employees and plant customers. With a sense of social responsibility born of religious beliefs, especially the values of noble character practiced by the education of Sufism orders, Haji Abdullah Idris always utilizes his wealth to charity and to spend on the noble path. He always provided assistance to those in need and served the assistance request from sports organizations and social and political organizations such as Setiawan Belia and Federation of Malay Persons (PPMK) (Anisah, 2018).

In the busyness of serving a desire in the world of loyalty and his concern with intellectual interest, at the same time he was also on the destiny of being visited by various human beings who needed financial assistance and advice. This is clearly evident from the visit of a deaf, dusk and long-lost Muslim Indian man who often comes in silent night-time which disturbs the peace of the neighbours with strong voices of asking for food. Haj Abdullah urged a girl with her wife to prepare food for the Muslim Indian man. Not only that Indian Muslim, even all the guests who need his help are not welcome. Guests who are in need of assistance are all well-equipped and assisted only. In addition, there are guests who come with medical needs, which are to make bidders, to name new-borns, prayer for children who are on the exam, to ask for advice on various life issues and to ask questions about the world of Sufism. During the Japanese military rule, he did not mind helping those in distress including his friends who wanted to owe. His sense of concern with the public interest continued to dominate life's stand until the end of his life in 1996. It was evident from his personal stance that had not forgotten the safety and well-being of Malaysia from any undesirable disaster at every opportunity to pray after the prayer. (Mahirah, 2018).

ii. Politics

His exposure to politics is not merely a matter of reading even from the experience of Dato 'Perdana and is increasingly open when he is able to establish contacts with his two previous acquaintances, Haji Wan Mahmud Daud and Wan Ibrahim Mustafa, two prominent figures in social organizations, Setiawan Youth and political organization, Malay Youth Union (KMM) (Mahmud, 2002). Apart from both of them, his friendship with Haji Ahmad Mahir, a Kelantan scholar, graduated from al-Azhar University and became a mufti of Kelantan has exposed him to understand both domestic and foreign politics. Friendship with Haji Ahmad Mahir also opened his mind about the reality of the political upheaval of the Egyptian people and the Arab world.

The office space at his business factory has always been a place of political discussion with his friends like Haji Wan Mahmud, Wan Ibrahim Wan Mustafa and Haji Nik Nazir Haji Wan Musa as well as those from senior government officials such as Jaafar Mampak and Abdul Jalil Hamid. During his Japanese occupation, his position as an entrepreneur gave him a good deal of contact with Japanese military officers who often stopped to his factory located on the outskirts of the Kelantan River and 
near the Royal Tambling for a picnic and relaxing in the front yard of his factory. This relationship was used by her to save some Japanese prisoners from being tortured. After his war of office space became a place of internal and international political discussion among Kota Bharu's youth who later appeared as political figures such as Nik Hassan Yahya, Abu Bakar al-Ahmadi and Ishak Hamid. During the Malayan Union event, his warehouse became a place of discussion and a small gathering fuelled the struggle of the Malays against this colonial agenda. As a caring entrepreneur, he provided material assistance to the Kelantan Malay Federal Federation (PPMK) who won the effort to mobilize the people of Kelantan to stand up against the British plan that tried to undermine and undermine the power of the Malay rulers and the interests of the Malays. (Mahirah, 2018).

\section{iii. Patriotism}

In addition to educating his grandson by reading his histories collection book, Pak Mat Hassan has also huddle Haji Abdullah with the spirit of patriotism through the story of the stories of the greatness and courage of the ancestors who had been involved in becoming Patani Islamic Malay fighters against the defeat of the Siamese colonists. The story of the suffering of the war refugees in Kelantan after the 1830's "Enemy of Siam" in the family of Pak Mat Hassan was often poured into the ears of Haji Abdullah from childhood to adolescent. This is a powerful experience of applying the influence of patriotism to Haji Abdullah's identity. This spirit strengthened deeper through his association with Haji Ahmad Mahir, Haji Wan Mahmud and Wan Ibrahim Mustafa and with exposure to the readings of the rise of patriotism that sprouted in the Arab world and in India after the First World War.

The spirit of patriotism Haji Abdullah was evident during the ups and downs of the city of Kota Bharu with the outbreak of the Malay-Chinese dispute with the emergence of the Three-Star Army ruling of the Chinese-dominated Anti-Japanese People's Army (MPAJA) which supported the Communist Party of Malaya on August 16, 1945 after the withdrawal of Japanese troops. These militaries have taken the chest to take power for claiming their important role in defeating Japan. The Malays who were identified as cooperating with Japan had become targets to be killed with cruelty. The Sultan and Religious Council and custom of the Malay Kelantaanese who maintained good relations with Japan have been targeted for criticism. Some of the buildings of the Kelantan Islamic Religious Council have been damaged. Their wild actions have sparked Malay-Chinese disputes in Kota Bharu City which resulted in some Malays being killed (Mohamed, 1984).

Haji Abdullah Idris has shown his uneasiness with the development of this race when he realized that several mosques and surau have been hijacked and tried to be blamed for his glory. Haji Abdullah Idris appears to be involved in providing moral support and material assistance at the critical times that hit Kota Bharu for the past few days. At one point Haji Abdullah Idris participated in the thrust of the chest due to the motive of the religious struggle after the rumours of the Chinese incited by the Three Stars Army were moving to dominate the city of Kota Bharu including the Muhammadi Mosque. Armed with a machete in hand, he has been out on the road to defend the sanctity of Islam but can be relaxed by some neighbours. All these ends ended when the British Army (BMA) acted immediately to take over the government. With the encouragement of the same spirit of patriotism, Haji Abdullah later joined the parade against the Malayan Union after Friday's Prayer at Padang Merdeka. With the encouragement of the same spirit he also with the residents of Kota Bharu rose 
INTERNATIONAL JOURNAL OF ACADEMIC RESEARCH IN BUSINESS AND SOCIAL SCIENCES Vol. 8, No. 10, Oct. 2018, E-ISSN: 2222-6990 @ 2018 HRMARS

to support the movement of GEMPAR (Gabungan Patani Melayu Raya) aimed at supporting the struggle of the Patani Muslims after the murder of a bloody battle in Nyior Dusun, Patani in 1948. (Anisah, 2018; Mohamed, 1984).

\section{iv. History of Kelantan and Jawi Writings}

The role of Haji Abdullah Idris in the education system in the state of Kelantan cannot be denied through his work titled "Citra Kelantan" which is a historical reading material for the Kelantan State Education Department and Islamic Religious Council and Kelantan Malay Customs. The work was written by Dato' Perdana as his writer, but according to a well-known author, Ismail Che Daud, the actual fact of the book was the result of his assistant writing (Haji Abdullah). The confirmation of this work was written by Haji Abdullah Idris himself by his children (Anisah, 2018). He performed this writing with the directive of Dato' Perdana Menteri Nik Mahmud Ismail to produce a book of the history of Kelantan kings. Armed with various sources of reference materials collected by Dato' Perdana, he has succeeded in producing the book in his busy schedule for 5 years of service. He just stopped working with the state authorities as soon as he finished writing this book. This book was utilized by students and enthusiasts of Kelantan history and later proved to be one of the important reference material on the history of Kelantan kings.

His spirit of patriotism is not only defending the sanctity of religion and the Fatherland, but he is also very sensitive to the interests of the Malays. For him the jawi text is a legacy of grandparents who need to be guarded and uplifted. This is evident in his two articles in the Pengasuh magazine and the Utusan Melayu newspaper on two different occasions. In both his writings he has come to criticize those who are trying to marginalize the Malay texts should rise against the elements. Initially happened at the beginning of Hajj Abdullah Idris's engagement in writing when he argued with his own teacher, Muhammad Adnan Arifin who tried to suggest jawi standardization, which could be considered to lead to jawi's weakness. Both are valid 20 years later around the 1950 s. This debate arose when Awang el-Sarkam (Abdul Wahab Muhamad from Serkam, Melaka) was a Utusan Melayu journalist who tried to make the idea of ASAS 50, a well-known literary body belonging to Employees, literatures and journalists who wanted to replace the jawi text with roman texts. As a Malay boy who loves jawi writing tradition Haji Abdullah Idris has argued with Awang Sarkam in the Utusan Melayu newspaper. Haji Abdullah opposed this recommendation because for him jawi writing it was not desirable to be wiped out even the Malays needed to empower him because the jawi text was a reflection on one of the Malay identity.

\section{v. Music art}

Haji Abdullah's skill as an intellectual Sufis has earned the attention of a well-known Kelantan musician to meet him asking questions about religious views on the music world. He is meant to be Abdullah Bukhari, a magnificent viola swordsman and leader of a well-known Tala Wijaya Orchestra. The arrival of a respected figure in society when he is undergoing a life of seclusion (uzlah), has been well served in parallel with an open attitude in serving every member of society from any group. This visit was rather surprising to Haji Abdullah because around Kampung Kubang Pasu there were many scholars. Abdullah Bukhari asked about the law of music playing from the glass of Islamic teaching is a tribute to Haji Abdullah. 
Haji Abdullah stressed that music is a mechanism that can absorb the soul and the feeling of being sympathetic and harmonious that injects the realization of the greatness of the Creator and thus draws closer to the Almighty. Music can be a bridge connecting with the Most Holy Substance and bringing to the divine nature. The ability to play music is a divine gift that can be channelled to a good and pure purpose. Haji Abdullah Idris explanations" from the eyewear that describes how the songs and music during the recitation of the al-Sama have stimulated Abdullah Bukhari to inquire and deeply understand the nature of Sufism. Abdullah Bukhari has expressed his gratitude for the enlightenment given by Haji Abdullah Idris. Abdullah Bukhari acknowledged the essence of music that could apply the intimacy of a musician with the Supreme Being and this was his own experience during his swaying violations. His tears often flow as he enjoys the friction of friction (Mahirah, 2018).

\section{CONCLUSION}

The above exemplifies the skill of an intellectual Sufis that contributed to the awakening of the awareness of the Kelantan Islamic community and to the increased understanding of the community on the donation of the Ahmadiyya order to the progress of science and intellectual development in the state of Kelantan. All this reflects the manifestation of his achievement in realizing his accountability towards the interests of the general public. Reflecting on his appreciation of being a concerned Sufi with the environment, he often expressed his gratitude for the aid of generous charity and divine guidance until he was able to contribute his energy stock, time, wealth and mind to the benefit of society. It is obvious here with all the above views that he is a Sufi activist for being able to self-centred and moving in various forms of welfare, social and scientific work to various stages of the people.

\section{ACKNOWLEDGEMENT}

This article is part of a research fund sponsored and managed by the Center for Research and Innovation (RMIC), Sultan Zainal Abidin University (UniSZA), Gong Badak Campus 21300 Kuala Nerus, Terengganu, Malaysia.

\section{REFERENCES}

Anisah A., daughter of Haji Abdullah Idris, interviewed on 06th. May 2018, at Rumah Kg. Kubang Pasu, Kota Bharu, at 09.30 p.m. - 12.00 p.m.

Auni A., daughter of Haji Abdullah Idris, interview on 17th. August 2017, at Rumah Kg. Lundang, Kota Bharu, at 10.00 p.m. - 12.00 p.m.

Daud I.C. (2012), Tokoh Ulama Tokoh Melayu Peninsular (1), Kelantan: Majlis Agama Islam Dan Adat Istiadat Melayu Kelantan.

Harun M.F. (2015), Tasawwuf and Tarekat; History of development and its Trends in Malaysia, Universiti Utara Malaysia Publisher, Sintok.

Mahirah A., daughter of Haji Abdullah Idris, interview on 10th. May 2018, at Rumah Kg. Kubang Pasu, Kota Bharu, at 09.30 p.m. - 12.00 p.m.

Mahmud A.R. (2002), Overview of Kelantan History, Kota Bharu: Pustaka Aman Press Sdn. Bhd.

Mohamed A. (1984), Kelantan's Social and Political Movement, Insular Publishing House Sdn.Bhd, Kuala Lumpur 
INTERNATIONAL JOURNAL OF ACADEMIC RESEARCH IN BUSINESS AND SOCIAL SCIENCES

Vol. 8, No. 10, Oct. 2018, E-ISSN: 2222-6990 ㄷ 2018 HRMARS

Rahman M.A., a nephew of Haji Abdullah Idris, interviews on the 11th. December 2017, at Jalan Raja Dewa Telipot, Kota Bharu, 05.00 p.m.-7.00 p.m.

Salam Y.A. (1988), Awrad al-Awlia', Kelantan Islamic Religious Council. 